\title{
Angka Bebas Jentik Aedes sp Sebelum dan Sesudah Pemberian Tanaman Repelent di Daerah Endemis DBD Kelurahan Mojosongo Solo
}

\author{
Aedes sp Authentic Free Numbers Before and After Preparing Repellent Plants in Area Endemis \\ DBD Mojosongo Solo
}

Tri Mulyowati*

Fakultas ilmu Kesehatan Universitas Setia Budi *Corresponding author : trimulyowatiusb81@gmail.com

\begin{abstract}
ABSTRAK
Jumlah kasus DBD di Kota Solo selalu meningkat, tahun 2016 sekitar 751 kasus dan 15 orang meninggal. daerah endemis demam berdarah di Solo cukup besar,diantaranya yang termasuk daerah endemis adalah kelurahan Mojosongo. Berdasarkan laporan pengamatan penyakit dari Puskesmas selama tahun 2016 ditemukan kasus sebanyak 751 yang tersebar di 17 wilayah Puskesmas jumlah kasus terbanyak di wilayah Gambirsari 206 kasus, wilayah Puskesmas Sibela 133 Kasus, , Tindakan pengendalian vektor diantaranya melakukan promosi tentang pencegahan dan penanggulangan penyakit Demam Berdarah melalui kegiatan JUSE (Jumat Sehat), Musyawarah Masyarakat Desa di Semua Kelurahan sampai tingkat RW, Pemberantasan Sarang Nyamuk, Pemantauan Jentik Berkala, Larvasidasi selektif. Angka bebas Jentik dilakukan dengan pemeriksaan tempat perkembangbiakan di dalam dan di luar rumah dari 100 rumah yang terdapat di daerah pemeriksaan. Indikator yang digunakan diantaranya House index, Container index dan Breteu index (Agoes dan Natadisastra, 2009).

Jenis penelitian ini adalah penelitian observasional dengan pendekatan cross-sectional pengambilan sampel menggunakan simple random sampling Metode yang digunakan adalah survey jentik dengan Metode single larva dan Metode Visual, setelah dilakukan survei dengan metode diatas, pada survei jentik nyamuk Aedes aegypti akan dilanjutkan dengan pemeriksaan House Index, Countainer index dan Breteu indek dan dihitung Angka Bebas jentik Aedessp.

Berdasarkan hasil penelitian yang sudah di lakukan dapat disimpulkan bahwa House index sebelum pemberian tanaman repelent sebesar $6 \%$ dan House index sesudah pemberian tanaman sebesar $4 \%$, Countainer index sebelum pemberian tanaman repelent sebesar 1,4\% dan Countainer index sesudah pemberian tanaman repelent sebesar 1,1,\%, Breteu index sebelum pemberian tanaman repelent sebesar 7\% dan Breteu index sesudah pemberian tanaman repelent sebesar 5\%, Angka bebas jentik Aedes sebelum pemberian tanaman repelent sebesar 93\% dan sesudah pemberian tanaman repelent sebesar $96 \%$.
\end{abstract}

Kata kunci: Angka Bebas Jentik Aedes sp, endemis DBD

\section{ABSTRACT}

The number of DHF cases in Solo always increases, in 2016 about 751 cases and 15 people died. the endemic areas of dengue fever in Solo are quite large, including those belonging to endemic areas are Mojosongo urban village. Based on reports of disease surveillance from Puskesmas during the year 2016 found 751 cases spread in 17 areas Puskesmas most cases in the area Gambirsari 206 cases, Sibela Health Center 133 Cases, vector control measures such as promoting the prevention and control of dengue fever through activities JUSE (Healthy Friday), Deliberation of Village Communities in All Villages to $R W$ level, Mosquito Nest Eradication, Periodic larvae Monitoring, Selective larvalidation. The larva-free number is performed by inspection of breeding grounds inside and outside the home of 100 houses located in the examination area. Indicators used include House index, Container index and Breteu index (Agoes and Natadisastra, 2009).

The type of this research is observational research with cross-sectional approach of sampling using simple random sampling The method used is larvae survey with single larvae method and Visual method, after survey with the above method, the survey of Aedes aegypti mosquito larvae will be followed by House Index, Countainer index and Breteu index and Calculated Free Rate oflarvae Aedes sp.

Based on the results of research that has been done can be concluded that the House index before the repelent plant 
$6 \%$ and House index after the planting of $4 \%$, Countainer index before the repelent plant $1.4 \%$ and Countainer index after the repelent plant 1, 1\%, Breteu index before repelent plant $7 \%$ and Breteu index after repelent plant $5 \%$, Aedes larvae free number before repelent plant $93 \%$ and after repelent plant $96 \%$.

Keywords: Aedes sp Authentic free numbers, DBD endemic

\section{PENDAHULUAN}

Demam Berdarah Dengue (DBD) termasuk penyakit menular yang disebabkan oleh infeksi virus dengue (DEN-1, DEN-2, DEN-3, atau DEN-4) yang ditularkan melalui gigitan nyamuk Aedes aegypti. Penyakit DBD di Indonesia pertama kali dicurigai di Surabaya dan Jakarta pada tahun 1968, kemudian berturut-turut dilaporkan di Bandung dan Yogyakarta pada tahun 1972. Menurut data Badan Kesehatan Dunia (WHO), Asia Pasifik menanggung 75 persen dari beban dengue di dunia antara tahun 2004 dan 2010, sementara Indonesia dilaporkan sebagai negara ke-2 dengan kasus DBD terbesar di antara 30 negara wilayah endemis (Kemenkes, 2014)

Jumlah penderita DBD telah mencapai 16.803 orang dan 267 orang di antaranya meninggal dunia berdasarkan data Departemen Kesehatan Indonesia pada awal tahun 2007 (Ginanjar, 2009). Penyakit DBD dapat menyerang semua orang dan dapat menyebabkan kematian terutama pada anak-anak serta sering menimbulkan kejadian luar biasa (KLB) atau wabah. Jumlah DBD meningkat antara bulan September sampai Februari dan puncaknya di bulan Januari (Misnadiarly, 2009).

Menurut data Departemen Kesehatan Indonesia pada awal tahun 2007 jumlah penderita DBD telah mencapai 16.803 orang dan 267 orang di antaranya meninggal dunia (Ginanjar, 2009). Penyakit DBD dapat menyerang semua orang dan dapat menyebabkan kematian terutama pada anak-anak serta sering menimbulkan kejadian luar biasa (KLB) atau wabah.

Berdasarkan kasus DBD dan DD tahun 2016 Kota Surakarta merupakan daerah endemis penyakit DBD dan 5 kecamatan yang ada semua merupakan daerah endemis dari 51 kelurahan hanya 7,84\% (4 Kelurahan yang bebas DBD yaitu Kelurahan Laweyan, Kedunglumbu, kepatihan Wetan dan Ketelan), sisanya Kelurahan endemis 29 Kelurahan dan 18 kelurahan Sporadis (Dinkes Kota Surakarta, 2017). Jumlah kasus DBD di Kota Solo dari tahun ke tahun selalu meningkat, tahun 2016 sekitar 751 kasus dan 15 orang meninggal. Daerah endemis demam berdarah di Solo cukup besar, di antaranya yang termasuk daerah endemis adalah kelurahan Mojosongo dan Kadipiro. Berdasarkan laporan pengamatan penyakit dari Puskesmas selama tahun 2016 ditemukan kasus sebanyak 751 yang tersebar di 17 wilayah Puskesmas jumlah kasus terbanyak di wilayah Gambirsari 206 kasus, wilayah Puskesmas Sibela 133 Kaus, Gilingan 63 Kasus, Purwosari 52 kasus, Tindakan pengendalian vektor diantaranya melakukan promosi tentang pencegahan dan penanggulangan penyakit Demam Berdarah melalui kegiatan JUSE (Jumat Sehat), Musyawarah Masyarakat Desa di Semua Kelurahan sampai tingkat RW, Pemberantasan Sarang Nyamuk, Pemantauan Jentik Berkala, Larvasidasi selektif, Penyelidikan Epidemiologi setiap ada kasus dan fogging focus. Angka bebas Jentik dilakukan dengan pemeriksaan tempat perkembangbiakan di dalam dan di luar rumah dari 100 rumah yang terdapat di daerah pemeriksaan. Indikator yang digunakan diantaranya House index, Container index dan Breteu index (Agoes dan Natadisastra, 2009). Data yang ada menunjukkan kepadatan populasi Aedes aegypti masih tinggi, diperkirakan $20 \%$ atau $5 \%$ di atas ambang penularan (Soeroso et al., 2004), bahkan di beberapa kota jauh lebih tinggi, House index di Kota Palembang 44,7\% (Budiyanto, 2005), di Jakarta Utara 27,3 \% (Hasyimi dan Soekirno, 2004). 
Hampir semua RW di Kelurahan Mojosongo merupakan daerah endemis DBD di Solo yang letaknya juga sangat berdekatan dengan Kampus Universitas Setia Budi di mana banyak sekali warga dan mahasiswa yang tinggal di sekitar kampus, hal ini sangat berbahaya jika tidak ada upaya untuk pencegahan dan penanggulangan DBD. Peneliti tertarik untuk melakukan penelitian tentang Perbedaan Angka Bebas Jentik Aedes sp sebelum dan sesudah pemberian tanaman Repelent pada daerah endemis, di Kelurahan Mojosongo Solo.

\section{METODE}

\section{Tempat Penelitian}

Tempat penelitian di Kelurahan Mojosongo yang merupakan wilayah kerja Puskesmas Sibela di RT 4 RW 04 Kelurahan Mojosongo.

Penelitian observasional dengan pendekatan cross-sectional yaitu penelitian untuk mempelajari dinamika korelasi antara faktor-faktor risiko dengan efek, dengan cara pendekatan, observasi atau pengumpulan data sekaligus pada suatu saat, dan teknik pengambilan sampel menggunakan simple random sampling (Notoatmodjo, 2002)

\section{Prosedur}

Prosedur Kerja penelitian adalah sebagai berikut:

\section{Survey jentik}

a. Metode single larva

mengambil satu larva yang ada di tempattempat penampungan air yang ditemukan ada larva/jentik nyamuk dan dilakukan identifikasi lebih lanjut mengenai jenis jentiknya apakah Aedes sp atau spesies yang lain.

b. Metode Visual

Survei jentik dengan melihat ada atau tidaknya larva di setiap tempat container air tanpa mengambil larvanya.

Setelah dilakukan survei dengan metode di atas, pada survei jentik nyamuk Aedes aegypti akan dilanjutkan dengan pemeriksaan House

\section{Index}

House Index (HI) adalah jumlah rumah positif jentik dari seluruh rumah yang diperiksa. $\mathrm{HI}=\frac{\text { Jumlah rumah yang positif jentik }}{\text { Jumlah rumah yang diperiksa }} \times 100 \%$

Container Index (CI) yaitu jumlah kontainer yang ditemukan larva dari seluruh kontainer yang diperiksa

$$
\mathrm{CI}=\frac{\text { Jumlah container yang positif jentik }}{\text { Jumlah cointener yang diperiksa }} \times 100 \%
$$

Breteu Index (BI) adalah jumlah kontainer dengan larva dalam seratus rumah.

$\mathrm{BI}=\frac{\text { Jumlah container yg positif jentik }}{100 \text { rumah yang diperiksa }} \times 100 \%$

\section{HASILDAN PEMBAHASAN}

\section{A. HASIL}

Penelitian dilakukan pada bulan Februari sampai April 2018 dengan menghitung Angka Bebas Jentik Aedes sp sebelum pemberian tanaman repellent dan sesudah pemberian tanaman repellent. Peneliti memilih Tanaman repellent untuk penelitian ini adalah tanaman Zodia (Evodia sauveolens) yang dibeli di Pasar Nongko Surakarta. Zodia termasuk tanaman yang masih tergolong dari suku jeruk-jerukan (Rutacea) dan merupakan tanaman endemik Indonesia yang berasal dari Papua tetapi kini tanaman zodia sudah mulai dibudidayakan di berbagai tempat. Sejak zaman dahulu Zodia digunakan oleh masyarakat khususnya masyarakat yang tinggal di daerah papua untuk mengusir serangga dan nyamuk dengan cara mengusapkan daun zodia ke seluruh tubuh, zodia juga bermanfaat sebagai anti-kanker. Tanaman zodia mengandung linalool (46\%) dan a-pinene (13,26\%), manfaat linalool sudah sangat dikenal sebagai pengusir (repellent) nyamuk. Penelitian yg pernah dilakukan daun zodia mampu menghalau nyamuk selama enam jam dengan daya halau (daya proteksi) sebesar lebih dari 70\%. Balai Penelitian Tanaman Rempah dan Obat (Balittro) juga pernah meneliti dengan gas kromatografi, minyak yang disuling 
dari daun zodia.

Aroma khas zodia tidak disukai nyamuk, karena adanya senyawa evodiamine dan rutaecarpine yang tidak disukai insekta ordo diptera seperti nyamuk. Daun zodia dapat menghalau nyamuk selama enam jam dengan daya halau (Daya Proteksi) sebesar lebih dari $70 \%$, selain itu lengan yang digigit oleh nyamuk demam berdarah akan cepat sembuh (Bentol dan Gatal) apabila digosok dengan daun zodia.

Penelitian ini dilakukan di Daerah endemis DBD Kelurahan Mojosongo dengan memeriksa 100 rumah di RW 04 RT 04 yang total jumlah KK di RW tersebut sejumlah 186 KK

1. Hasil Survey Jentik dan Pemeriksaan Mikroskopis

Survey jentik bertujuan mendapatkan proporsi CI, HI dan ABJ. Metode yang dilakukan dengan menggunakan metode single larva dan metode visual setelah ditemukan dilakukan pengamatan mikroskopis jentik untuk memastikan spesies Aedes sp, selain itu ditemukan juga adanya pupa di dalam cointener.

Ciri-ciri yang menunjukkan bahwa spesies yang ditemukan adalah larva mempunyai sifon pendek pada segmen ke VIII dengan satu berkas rambut di seberang distal pekten, warna lebih gelap daripada abdomen, pada waktu istirahat sifon membentuk sudut dengan permukaan air.

Ciri - ciri yang menunjukkan adanya pupa Aedes sp adalah bentuk tubuh bengkok dengan bagian kepala-dada lebih besar dibandingkan dengan bagian perut seperti koma, pada bagian punggung dada terdapat alat bernafas dan ruas perut ke-8 terdapat sepasang alat pengayuh untuk berenang.

\section{B. PEMBAHASAN}

Berdasarkan hasil di atas Angka bebas jentik Aedes sp sebelum pemberian tanaman repellent sebesar $93 \%$ artinya angka tersebut masih di bawah standar nasional yang diharapkan dari Kemenkes yaitu di bawah 95\%, hal ini dikarenakan kesadaran masyarakat dalam berpartisipasi dalam PSN masih agak kurang misalnya masih ditemukanya banyak barang - barang bekas di luar rumah yang tidak dikubur atau disingkirkan sehingga ketika ada air hujan masuk dan menjadi tempat perkembangbiakan nyamuk Aedes sp. Informasi yang diberikan oleh kader yang bertugas sebagai Jumantik juga Pemantauan Jentik Berkala masih dilaksanakan 2 minggu sekali untuk mengisi checklist yang dipasang di setiap rumah sehingga masih kurang efektif yang seharusnya dilakukan seminggu sekali. Kader yang mendominasi dalam upaya pencegahan DBD dengan bertugas sebagai Jumantik. Hasil penelitian yang pernah dilakukan Salawati pada tahun 2010 juga menyebutkan bahwa praktik PSN yang berhubungan dengan kejadian DBD di antaranya yaitu menutup dan menguras tempat penampungan air dan terbiasa menyingkirkan barang bekas sehingga angka kejadian Demam Berdarah Dengue akan menurun.

Angka Bebas Jentik Aedes sp sesudah pemberian repellent sebesar $96 \%$ sehingga sudah di atas standar nasional yang diharapkan Kemenkes. Menurut Kemenkes RI tahun 2010 Apabila $\mathrm{ABJ} \geq 95 \%$ maka diharapkan penularan DBD bisa dikurangi. Keberhasilan suatu PSN dapat diukur pada keberadaan vector. Masyarakat sudah sadar akan pentingnya mencegah penya-

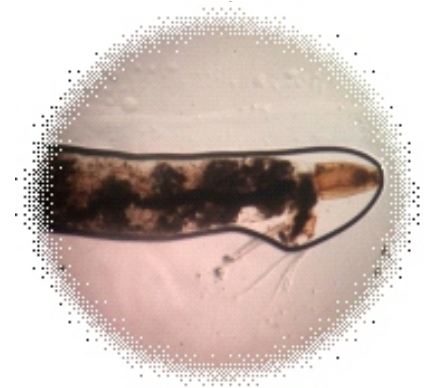


kit DBD setelah ada komunikasi secara langsung dengan peneliti apabila ditemukan jentik di rumahnya langsung diberi saran untuk menguras secara rutin bak mandi air atau menggunakan larvasida abate, selain itu juga merawat tanaman zodia yang sudah dibagikan satu-satu di setiap rumah. Tanaman repellent sangat bermanfaat untuk mengusir nyamuk dewasa sehingga nyamuk tidak akan berkembangbiak di sekitar rumah karena kalo mengadakan perkembangbiakan akan menjadi telur dan menjadi larva dan pupa akan meningkatkan kemungkinan kepadatan populasi yang dampaknya bisa meningkatkan angka kejadian DBD di masyarakat.

\section{KESIMPULAN}

Berdasarkan hasil penelitian yang sudah dilakukan dapat disimpulkan sebagai berikut

1. House index sebelum pemberian tanaman repelent sebesar 6\% dan House index sesudah pemberian tanaman sebesar $4 \%$.

2. Countainer index sebelum pemberian ta- naman repelent sebesar $1,4 \%$ dan Countainer index sesudah pemberian tanaman repelent sebesar $1,1 \%$.

3. Breteu index sebelum pemberian tanaman repelent sebesar 7\% dan Breteu index sesudah pemberian tanaman repelent sebesar $5 \%$.

4. Angka bebas jentik Aedes sebelum pemberian tanaman repelent sebesar $93 \%$ dan sesudah pemberian tanaman repelent sebesar $96 \%$.

\section{DAFTAR PUSTAKA}

Agoes, R dan Natadisastra D. 2009. Parasitologi Kedokteran di tinjau dari organ tubuh yang diserang.Penerbit Buku Kedokteran EGC. Jakarta.

Budiyanto. A. 2005. Studi Indeks Larva Nyamuk Aedes aegypti dan Hubunganya dengan PSP masyarakat tentang Penyakit DBD di Kota Palembang Sumatera Selatan. http://www.balitbang.depkes.id.

Dinkes Kota Surakarta, 2017. Profil Kesehatan Kota Surakarta Tahun 2016

Ginanjar, G. 2009. Demam Berdarah. Mizan Publika. Jakarta.

Hasyimi M,Soekirno M. 2004. Pengamatan Tempat Perindukan Aedes aegypti pada tempat Penampungan Air Rumah Tangga pada Masyarakat pengguna air olahan. Ekologi Kesehatan. 3(1) 37-34.

Kemenkes. 2014. Profil kesehatan Indonesia

Misnadiarly. 2009. Demam Berdarah Dengue: Ekstrak Daun Jambu Biji Bisa untuk mengatasi DBD, edisi 1, Pustaka Populer Obor, Jakarta

Notoatmodjo, S. 2002. Metodologi Penelitian Kesehatan. Rineka Cipta. Jakarta. 